\title{
MAINTAINING THE MENTAL HEALTH \\ OF THE BORDER GUARDS IN SPECIAL AND/OR EXTREME \\ CONDITIONS OF THEIR PROFESSIONAL ACTIVITY \\ BY MEANS OF THE PASTORAL ACTIVITY \\ OF THE MILITARY CHAPLAINS
}

\section{Artem Makovskyi}

"Religious faith made sense of life even in the terrible conditions of Auschwitz" Viktor E. Frankl

\section{INTRODUCTION}

Today, in the period of socio-historical and socio-economic upheavals, there is a significant increase in extreme psychological situations in the everyday life of the Ukrainian citizens, which are characterized by significant influence on the human psyche of sociopsychological factors related to the threat to life, health or social wellbeing, the psychological consequences of which are manifested in occurrence of various kinds of negative psycho-emotional reactions, both in the Ukrainian society in general and among the border guards in particular. The undeniable fact is the one that the constant threat to life, combat wounds or contemplation of death are extraordinary psycho-traumatic factors, which determine the border guards' stress that can transform into a psychological trauma and lead to mental health disorders.

According to the definition of the World Health Organization "mental health" is a level of mental well-being, which is determined not only by the absence of mental illnesses, but also by a number of socio-economic, biological and environmental factors ${ }^{1}$ ("Vsesvitnia orhanizatsiia okhorony zdorovia", 2019).

1 Vsesvitnia orhanizatsiia okhorony zdorovia [World Health Organization]. Retrieved from: https://www.who.int/ru/news-room/fact-sheets/detail/mental-healthstrengthening-our-response [in Ukrainian]. 
The "Psychological Dictionary" gives the following definition of the concept of "mental health": "a state of a person's mental wellbeing, which is characterized by the absence of painful mental manifestations and provides the regulation of his behavior and activity in adequate conditions of reality"2 (Pobirchenko, 2007). Considering the multidimensionality, diversity of the psyche, Ye. Potapchuk distinguishes the basic components or types of a person's mental health: a mental type - the ability to receive, analyze and use the necessary information; an emotional type - the ability to understand, express and regulate one's own emotions and feelings; a practical one - the ability to understand one's own needs and interests, to set appropriate goals and achieve them ${ }^{3}$ (Potapchuk, 2004).

Having analyzed the scientific works of the Ukrainian military psychologists, we came to the conclusion that the concept of "mental health of a border guard" should be considered as such a way of his psyche functioning, which provides a harmonious interaction with the outside world, the adequacy of behavior, the effectiveness of educational and service activities, personal development ${ }^{4}$ (Aleshchenko, Safin, \& Potapchuk, 2007).

Studies of warfare experience indicate that the mental health of the border guards is positively influenced by the formed combat skills, voluntary participation in combat operations, integration into the unit, high moral climate in the unit, religiosity or belief in war justice, high self-esteem and intelligence. Due to the objective lack of a sufficient number of specialists, i.e. psychologists with practical experience in the border guard units, the approach to psychological prevention and psychological correction of psychological trauma of the personnel of

${ }^{2}$ Pobirchenko, N. A. (Red.). (2007). Psykholohichnyi slovnyk [Psychological Dictionary]. Kyiv: Naukovyi svit [in Ukrainian].

${ }^{3}$ Potapchuk, Ye. M. (2004) Sotsialno-psykholohichni osnovy zberezhennia psykhichnoho zdorovia viiskovosluzhbovtsiv [Socio-psychological bases of maintaining mental health of military personnel]. (Dys. d-ra psykhol. nauk) Natsionalna akademiia Derzhavnoi prykordonnoi sluzhby im. B. Khmelnytskoho, Khmelnytskyi [in Ukrainian].

${ }^{4}$ Aleshchenko, V. I., Safin O. D., Potapchuk Ye. M. (2007). Orhanizatsiia zabezpechennia zberezhennia psykhichnoho zdorovia viiskovosluzhbovtsiv [Organization of maintenance of mental health of military personnel]. Kyiv [in Ukrainian]. 
the State Border Guard Service of Ukraine remains unavoidably formal. Therefore, in our opinion, during the conduct of psychoeducational, informative-propagandist and psycho-prophylactic measures with border guards, the potential of military chaplains, who have been providing pastoral care for the military personnel on a regular basis for the last three years, should be used more actively.

First of all, it is necessary to find out who a military chaplain is and how he differs from a parish priest.

1. A military chaplain is a priest or a spiritual leader of a religious community. He can be a pastor, a minister, a rabbi, an imam. In some Protestant churches he is a deacon with the priesthood authority.

2. A military chaplain is associated with a particular denomination or a religious organization and he is its representative in the army. But he gives spiritual support to people of any religion neither imposing his religious views on others nor giving up his own beliefs.

3. A military chaplain gives spiritual support to a group of people who do not represent a church, religious, or missionary community. By the silent agreement, a kind of world code of military chaplaincy, the army cannot be a field of missionary activity.

4. A military chaplain is no ordinary priest. He received a special training in the field of pastoral care of soldiers. There is no generally accepted standard (among states, denominations, or even just educational institutions) for training military chaplains. In some church educational institutions, he may be trained as a psychologist purposefully.

5. A chaplain usually gives spiritual support to everyone, regardless of his faith or its lack.

6. A military chaplain operates in a particular human environment. His congregation is physically strong, active, armed, and (on the general public background) highly aggressive ${ }^{5}$ (Kalenychenko, \& Kokhanchuk, 2017).

We suggest considering a few problematic aspects in the moral and psychological support of the border guards where, in our opinion,

${ }^{5}$ Kalenychenko, T., Kokhanchuk, R. (2017). Buty poruch. Osnovy viiskovoho kapelanstva dlia viiskovykh $i$ volonteriv [To be near. Basics of military chaplaincy for military personnel and volunteers]. (2-e vydannia). Kyiv: Makhanaym Prynt [in Ukrainian]. 
it is necessary to activate the pastoral activities of military chaplains in order to maintain the mental health of the personnel in special and/or extreme conditions of their professional activity.

\title{
1. Psychological prevention of deviant behavior of the border guards in special and/or extreme conditions of their professional activity by means of pastoral activity of military chaplains
}

\author{
"Chaplains are strong-minded people \\ who dress the Ukrainian army in the armor of light" \\ His Beatitude Sviatoslav
}

Over the last five years, more than 17,000 border guards have participated in hostilities in the East of the country that are characterized by a significant impact on their psyche of socio-psychological factors related to the threat to life, health or well-being, the psychological effects of which are expressed in different forms of deviant behavior.

In the Great Interpretive Dictionary of Modern Ukrainian, deviance is defined as social behavior that deviates from what is considered normal or socially acceptable in the society or in a social context $^{6}$ (Busel, 2005). In psychological dictionaries, deviant behavior is defined as:

Deviant behavior is behavior that violates the social norms of a particular society ${ }^{7}$ (Reber, 2003).

Deviant behavior includes actions that do not conform to officially established or actually formed in this society (social group) norms and leads the offender to isolation, treatment, correction or punishment $^{8}$ (Meshcheryakova, \& Zinchenko, 1983).

At the roots of sociology of deviant behavior there was French scientist Emile Durkheim (1858-1917), the creator of the French

\footnotetext{
${ }^{6}$ Busel, V. T. (Red.). (2005). Velykyi tlumachnyi slovnyk suchasnoi ukrainskoi movy [A great explanatory dictionary of modern Ukrainian]. Kyiv: Perun [in Ukrainian].

${ }^{7}$ Reber, A. (Red.). (2003). Bolshoy tolkovyy psikhologicheskiy slovar [Great explanatory psychological dictionary]. (T. 1 (A-O)). Moskva: AST [in Russian].

${ }^{8}$ Meshcheryakova, B. G., Zinchenko, V. P. (Red.). (1983) Psikhologicheskiy slovar [Psychological Dictionary]. Moskva: AST [in Russian].
} 
sociological school. He put forward the concept of social anomie, defining it as "a state of society when old norms and values do not correspond to real relations anymore and new ones have not been established yet". In his opinion, anomie is a consequence of crises and different social changes and it describes such a situation in a society that is characterized by the weakening or destruction of norms, the contradictions of the rules, which regulate social relations. As a result, individuals lose their social orientation, which contributes to the development of their deviant behavior. Thus, in his work "Suicide" Durkheim noted that during the periods of social declines and upsurges, the number of suicides increased, showing that social disorganization is the cause of deviant behavior ${ }^{9}$ (Durkheim, 1994).

The opinion of I. Kon is that deviant behavior is a system of actions that deviate from the accepted norm or the implied one (mental health, rights, morals) ${ }^{10}$ (Kon, 1997).

M. Kikalishvili proposes the following definition of deviant behavior: it is a person's stable behavior, which deviates from the most important social norms and causes real harm to the society or the person himself, and is accompanied by his social maladaptation ${ }^{11}$ (Kikalishvili, 2001).

The special features and factors of deviant behavior of a person are widely described in the theory of psychology: firstly, in the process of age development (L. Vygotskyi, E. Erikson, Yu. Kleiberg, O. Rean, H. Remscheid); secondly, in the process of adaptation to the environment (V. Mendelevich, Yu. Platonov, etc.); thirdly, in connection with the development of methods of socio-psychological prevention and correction of individual-psychological manifestations of deviant behavior (O. Zmanovska).

9 Durkheim, E. (1994). Samoubiystvo: Sotsiologicheskiy etyud [Suicide: A sociological study]. Moskva: Mysl [in Russian].

${ }^{10}$ Kon, I. S. (1997). Vkus zapretnogo ploda [The taste of the forbidden fruit]. Moskva: Semya i shkola [in Russian].

${ }^{11}$ Kikalishvili, M. (2001). Deviantna povedinka: poniattia ta oznaky [Deviant behavior: concepts and features]. Visnyk Akademiii advokatury Ukraiiny [Bulletin of the Academy of Advocacy of Ukraine], 3(22), 109-122. Retrieved from: irbisnbuv.gov.ua > cgi-bin > irbis_nbuv > cgiirbis_64 > vaau_2011_3_17 [in Ukrainian]. 
Deviant behavior is generally the subject of scientific analysis in many studies by foreign psychologists and is considered as: the result of insufficient containment of internal tension that requires discharge; the consequence of hypercompensation of needs (A. Adler, Z. Freud, E. Fromm); the result of social learning (A. Bandura); the consequence of frustration (J. Dollard, N. Miller); a consequence of the blockade of self-actualization needs (A. Maslow), etc.

The manifestations of deviant behavior of the military personnel were researched by modern scientists: V. Aleshchenko, O. Blinov, O. Boiko, O. Makarevych, Ya. Melnyk, V. Osodlo, I. Prykhodko, A. Romanyshyn, V. Timchenko, V. Yahupov and others.

According to I. Kon, persons with deviant behavior are divided into two broad categories. The first category includes those persons, whose behavior deviates from mental health standards, i.e. it can be confirmed that they have manifested or hidden psychopathology. The second category comprises those persons with asocial (delinquent) behavior, the special feature of which is the violation of social, cultural and legal norms ${ }^{12}$ (Kon, 1967).

The well-known researcher in the field of deviant behavior typology A. Lychko classifies deviant behavior according to the following directions:

1) by the form: delinquent behavior, home escape, early alcoholism, sexual deviance, suicidal behavior;

2) by reasons, factors, motives: genetic inheritance, residualorganic brain damage, phenomena of acceleration and infantilism - on the one hand, and sociopsychological factors - on the other hand ${ }^{13}$ (Lichko, 1983).

According to Ya. Melnyk, deviant behavior of the military personnel is a socio-psychological phenomenon, the content base of which is a violation of social-psychological interaction of a military man with the military and social environment, which is caused by inconsistencies in the system of "person - military-social environment"

${ }^{12}$ Kon, I. S. (1967). Sotsiologiya lichnosti [Sociology of personality]. Moskva: Politizdat [in Russian].

${ }^{13}$ Lichko, A. Ye. (1983). Eti trudnyye podrostki [These difficult teens]. Moskva: Meditsina [in Russian]. 
that are defined by his actions and deeds that do not comply with the military organization norms ${ }^{14}$ (Melnyk, 2016).

A considerable number of offenses and negative phenomena in combat units actualizes the task of preventing and overcoming deviant behavior of the border guards in special and/or extreme conditions of their professional activity. The large number of suicides is of particular concern.

Suicidal behavior is a self-destructive behavior that also includes such forms of deviant behavior as alcohol abuse, drug use, stubborn unwillingness to be treated, drunk driving, self-torture, conscious participation in fights, etc ${ }^{15}$ (Romanyshyn, 2017).

According to statistics, more than 800,000 people die in the world annually as a result of suicides, i.e. one person every 40 seconds (one of the most vulnerable groups is the youth $)^{16}$ (Ovcharova, \& Movchan, 2018). According to the State Statistics Service in Ukraine, in 2015-2016, 14773 persons committed suicides. Currently, the suicide is the second leading cause of death for people aged 15 to 29 in the world ${ }^{17}$ (Derzhavna sluzhba statystyky Ukrainy, 2018). According to official figures, more than 500 Ukrainian military men have committed suicide since the beginning of hostilities in the East of the country ${ }^{18}$

14 Melnyk, Ya. I. (2016). Psykhoprofilaktyka deviantnoi povedinky viiskovosluzhbovtsiv v osoblyvykh umovakh diialnosti [Psychoprophylaxis of deviant behavior of military personnel in special conditions of activity]. (Dys. kand. psykhol. nauk). Natsionalna akademiia Derzhavnoii prykordonnoii sluzhby im. B. Khmelnytskoho [in Ukrainian].

15 Romanyshyn, A. M. (Red). (2017). Profilaktyka vidkhylnoi povedinky $u$ viiskovosluzhbovtsiv [Prevention of deviant behavior of military personnel]. Lviv: NASV [in Ukrainian].

16 Ovcharova, L., Movchan, A. (2018.). Technologies of social work with persons easy to suicide REPORTER OF THE PRIAZOVSKYI STATE TECHNICAL UNIVERSITY Section: Socially-humanitarian sciences and public administration, 1, 119-122 [in English].

${ }^{17}$ Derzhavna sluzhba statystyky Ukrainy [State Statistics Service of Ukraine]. (2018). Lyst [Letter]. Retrieved from: ps://dostup.pravda.com.ua/request/34337/ response/76881/attach/2/15.2\%2020\%20770.pdf [in Ukrainian].

18 Samohubstva v armii [Suicide in the Army]. (2018, liutyi 26). Ukrainska Pravda [The Ukrainian Truth]. Retrieved from: https://www.pravda.com.ua/news/ 2018/02/26/7172855 [in Ukrainian]. 
("Samohubstva V armii", 2018). According to unofficial information, this number is much higher ${ }^{19}$ ("Vlada znaie ne vse...", 2018).

Most European countries use the definition adopted by the Working Group on Suicide Prevention and Suicide Attempts at the World Health Organization's Regional European Office: "Suicide is an act with fatal outcome that was initiated and executed by the one, who died, deliberately in an awareness and expectation of fatal result by which the deceased realized the desired change". Thus, the suicide is an escape from the reality, which is perceived as hostile (from the point of view of the suicide committer) and the point of suicide is to solve all problems irrevocably. Among the factors, which contribute to thoughts about suicide, are social isolation, lack of support from relatives and friends in a difficult situation, problems at military service, problems of interpersonal relationships, etc.

The researchers in the field of military psychology usually distinguish the following types of a suicide:

- real (conscious, "steadfast", planned, purposeful);

- affective (it occurs under the influence of a sudden psychotraumatic event);

- demonstrative (does not include committing suicide $)^{20}$ (Karayani, 2006).

Unfortunately, all these types of suicides also occur in the State Border Guard Service of Ukraine. By its nature, suicide among the border guards is usually a form of infantile escape from a psychotraumatic situation.

Therefore, the psychoprophylaxis is one of the most important areas of work on suicide prevention for the management staff of the border guard unit, a psychologist, a military chaplain and its success depends mainly on their ability to recognize the signs of suicidality in the behavior of the border guard. Practice has shown that a border

19 Vlada znaie ne vse... [The authorities do not know everything...] OBOZREVATEL.ua. [OBSERVER.ua] Retrieved from: https://www.obozrevatel.com/ $\mathrm{ukr} /$ crime/statistika-zanizhena-veteran-ato-rozpoviv-pro-vbivstva-i-suitsidi-v-armii.htm [in Ukrainian].

20 Karayani, A. G. (2006). Prikladnaya voyennaya psikhologiya [Applied Military Psychology]. Sankt-Peterburg: Piter [in Russian]. 
guard who is about to commit suicide, consciously or unconsciously, tries to inform others about the trouble in which he found himself as well as about a possible act of suicide. Among the signs of a possible suicide committing, the researchers single out the most common ones such as depression; oral or written hints which include considerations about suicide; stories about their problems; asking for help. Inattention to the problems of the border guard by the commander, the military chaplain, his comrades, his relatives and friends is an obstacle for responding to such signals in time.

Another type of deviant behavior that needs greater attention of commanders is the addictive behavior that results from substance abuse which change a person's mental state (alcohol, drugs, toxic substances) $^{21}$ (Romanyshyn, 2017). In all its various manifestations, addictive behavior, which is basically a distorted form of adaptation, overcoming anxiety, insecurity, social uncertainty, striving for selfaffirmation, can be considered a response to unfavorable living conditions and military service conditions. The most common form of addictive behavior among the military personnel is alcohol abuse, which, from a psychological point of view, is a kind of compensation, an attempt to disengage from a situation of lethal danger psychologically, to overcome fear, to forget about losses, etc. Unfortunately, some military men believe that the recovery from stress, the removal of psychological burden with alcohol is one of the most effective problem solutions. The commanders and psychologists of military units may not always be able to carry out effective psychoprophylactic measures aimed at preventing drinking As the practice of involving some chaplains by commanders in the fight against drinking in military units has shown, it has a positive effect.

The difficult circumstances in life that lead to frustration bring people closer to religion that becomes their means of hypercompensation. Mostly the combatants get interested in religion while they are in such a state. W. James noticed that religion has the wonderful power to turn the most enduring sufferings of the human

21 Romanyshyn, A. M. (Red). (2017). Profilaktyka vidkhylnoi povedinky u viiskovosluzhbovtsiv [Prevention of deviant behavior of military personnel]. Lviv: NASV [in Ukrainian]. 
soul into the deepest and most intimate happiness ${ }^{22}$ (Predko, 2005). The representatives of the humanistic approach in psychology, American scientists A. Maslow, C. Rogers, H. Kohut, came to the conclusion that the religiosity of a person influences his selfrealization, self-actualization, self-transcendence positively and it helps many people to realize their calling, realize their abilities, to choose a viable life strategy and tactics ${ }^{23}$ (Moskalets, 2004).

In the United States and Western European countries, psychological science has been using religion in psychoprophylactic activity thoroughly and effectively for a long time. In this activity, the role of the priest is decisive. Therefore, pastoral psychology has emerged as a separate branch of the psychology of religion in these countries. It is a branch of knowledge, the main problem of which is the ways and means of effective psycho-regulatory influence of the clergymen on the human psyche. And the military chaplains, who carry out the pastoral care of military men, play traditionally an exceptional role in the system of working with the army personnel of the NATO member state.

The history of the Ukrainian armed formations contains many examples of close interaction between the state and the church in its chronicle. The issue of chaplain pastoral care in Ukraine is gaining more and more importance and relevance in connection with the hybrid war. Military chaplains influence the spiritual and patriotic state of the military men, their families, and the Ukrainian society as a whole, because during almost the whole history of independent Ukraine, the church as a social institution, has always been first in the trust rating of the Ukrainian citizens ${ }^{24}$ (Nepipenko, 2017). The results of the field

${ }^{22}$ Predko, O. I. (2005). Psykholohiia relihii: istoriia, teoriia, relihiieznavchi vymiry [Psychology of Religion: History, Theory, Religious Dimensions]. Kyiv: Tsentr navchalnoi literatury [in Ukrainian].

23 Moskalets, V. P. (2004). Psykholohiia relihii [Psychology of religion] : posibnyk. Kyiv: Akademvydav [in Ukrainian].

${ }^{24}$ Nepipenko, L. P. (2017). Problemy ta perspektyvy instytualizatsii viiskovoho dukhovenstva (kapelanskoi sluzhby) $v$ Ukraini [Problems and Prospects of Institutionalization of the Military Clergy (Chaplaincy Service) in Ukraine], Naukove zabezpechennia sluzhbovo-boiovoi diialnosti Natsionalnoi hvardii Ukrainy [Scientific Support for Service and Combat Activity of the National Guard of Ukraine], zb. materialiv dop. uchasn. VIII nauk.-prakt. konf. Kharkiv: NANHU. Retrieved from: 
researches and expert assessments, which were conducted by T. Kalenychenko, indicate that each of the interviewed military men who participated in the warfare, mentions the importance of the priest presence nearby. In addition to the importance of the pastor's constant presence with them on the front line (which is relevant during the open phase of the conflict), some young officers advise to focus on the work of chaplains with the cadets who become field commanders shortly after their graduation and learn to manage their military unit immediately on the front line $\mathrm{e}^{25}$ (Kalenychenko, 2018).

Thus, psychoprophylactic work is based on the early detection and correction of negative informational, psychological and organizational factors of service and combat activity, which cause deviations in the psychological and social life of the border guards, in their behavior, health, and organization of their service and leisure activities. The Psychoprophylaxis of deviant behavior is a part of the program on its prevention, which cannot be carried out only by unit commanders and officers of educational structures, taking into consideration the foreign experience of the NATO armies. It is necessary to involve military chaplains as actively as possible in the psychoprophylaxis of suicidal and addictive behavior of the border guards, since religion has a powerful psychoprophylactic influence on the person's psyche, creating for him an opportunity to assert himself in the personal transcendent. The main psychoprophylactic effect of the pastoral care is the feeling of existential security as a consequence of suggesting the inevitability of the victory of good over evil, of life over death. At the same time, religion minimizes the source of existential anxiety, fear or even neutralizes it completely, it helps a person to establish himself psychologically in the highest authority that promises him protection from the threat of evil and death.

Thus, the pastoral activity of the military chaplains has a wide range of psychological techniques, capable of updating and adjusting

http://nangu.edu.ua/wp-content/uploads/2017/04/3бірник-тез-2017_секція-4.pdf [in Ukrainian].

25 Kalenychenko, T. A. (2018). Relihiina skladova suspilno-politychnoho konfliktu kintsia 2013-2017 rr. v Ukraini [The religious component of the sociopolitical conflict of the end of 2013-2017 in Ukraine]. (Dys. kand. filosof. nauk). Nats. ped. un-t. im. M.P. Drahomanova, Kyiv [in Ukrainian]. 
the subjective potential of the border guard and activating it for selfpreservation and protection of the Motherland.

\section{The prognostic model of the interaction of the subjects of moral-psychological support for maintaining the mental health of the border guards in special and/or extreme conditions of their professional activity}

According to the definitions of encyclopedic dictionaries, a model is considered as a diagram, depiction or description of any object, phenomenon or process in nature or society that are studied as their analogue (from Latin modulus - measure, sample) ${ }^{26}$ (Grishin, 1994). A model is any mental, symbolic or material image of the original (displaying objects and phenomena in the form of descriptions, theories, diagrams, drawings, graphs) ${ }^{27}$ (Prokhorov, 1991). The model is one of the central concepts of the theory of cognition, it is connected with the concepts of truth and thought, similarity, difference $^{28}$ (Shynkaruk, 1986). Model is a sample that reproduces, imitates the structure and action of any object; it is used to gain new knowledge about the object ${ }^{29}$ (Busel, 2005); model is a measure, a sample, a conditional image of something ${ }^{30}$ (Filonenko, 2015); model is a sign system with which you can reproduce the process, show the integrity of its structure, functioning and maintain that integrity at all the stages of the research ${ }^{31}$ (Spirina, 2008).

${ }^{26}$ Grishin, Ye. A. (Red). (1994). Sovremennyy slovar inostrannykh slov [Modern dictionary of foreign words]. Sankt Peterburg: Duyet [in Russian].

27 Prokhorov, A. M. (Red.). (1991). Bolshoy entsiklopedicheskiy slovar [Great Encyclopedic Dictionary]. Moskva: Sov. Entsiklopediya [in Russian].

${ }^{28}$ Shynkaruk, V. I. (Red). (1986). Filosofskyi slovnyk [Philosophical Dictionary] Kyiv: Holovna redaktsiia URE [in Ukrainian].

${ }^{29}$ Busel, V. T. (Red). (2005). Velykyi tlumachnyi slovnyk suchasno ukrainskoi movy [A great explanatory dictionary of modern Ukrainian]. Kyiv: Perun [in Ukrainian].

30 Filonenko, M. M. (2015). Psykholohiia osobystisnoho stanovlennia maibutnoho likaria [Psychology of personality formation of the future doctor]. Kyiv: Tsentr uchbovoii literatury [in Ukrainian].

31 Spirina, T. P. (2008). Model formuvannia profesiinoi kultury maibutnikh sotsialnykh pedahohiv [Model of professional culture formation of future social educators]. Visnyk Prykarpatskoho universytetu : pedahohika [Bulletin of the Carpathian University : Pedagogy], 21, 278-291 [in Ukrainian]. 
A scientific model is an imaginary or materially implemented system that adequately reflects the subject of the research and is able to change it in such a way that the study of the model facilitates to obtain new information about the subject. At the same time, the main advantage of modeling as a research method is the ability to cover the system holistically and it allows to improve its planning, to optimize the structure, to increase the process efficiency, to construct and interpret a new theory, to test the hypothesis of the research ${ }^{32}$ (Poplavska, 2009).

I. Levina defines a model as the construction of several constituents, the components of which are the subject (person); a task which is solved by the subject; the original object (fragment of reality) and the description language or the method of material reproduction of the model $^{33}$ (Levina, 2001).

The model gives an opportunity to understand what should be formed in comparison with what has already been formed. On the basis of the model, it is possible to formulate a general aspect of the process, transfer it into a theoretical plane, understand the structure and mechanism of interaction of the system under study better and it will ensure the reliability of processing the obtained results ${ }^{34}$ (Mykhailiuk, 2001).

Having generalized the experience of the scientists who dealt with modeling problems, I. Levina considered didactic functions of models and modeling, determined their essence and structure, carried out

${ }^{32}$ Poplavska, S. D. (2009). Model formuvannia hotovnosti studentiv medychnykh koledzhiv do komunikatyvnoi vzaiemodii u profesiini diialnosti [Model of forming the readiness of students of medical colleges for communicative interaction in the professional activity]. Visnyk Zhytomyrskoho DU im. I. Franka [Bulletin of I. Franko Zhytomyr State University], 46, 92-96 [in Ukrainian].

${ }^{33}$ Levina, I. A. (2001.). Profesiina diialnist uchytelia z formuvannia piznavalnoi samostiinosti pidlitkiv zasobamy modeliuvannia [Teacher's professional activity on forming of teenagers' cognitive independence by means of modeling]. (Dys. kand. ped. nauk.). Pivdennoukr. derzh. ped. un-t im. K. D. Ushynskoho, Odesa [in Ukrainian].

34 Mykhailiuk, I. R. (2001). Pedahohichni umovy ta model formuvannia hotovnosti do pedahohichnoi diialnosti mahistriv tekhnichnoho spriamuvannia [Pedagogical conditions and model of forming the readiness for pedagogical activity of masters of technical direction]. Visnyk Natsionalnoi akademii Derzhavnoi prykordonnoi sluzhby Ukrainy [Bulletin of the National Academy of the State Border Guard Service of Ukraine], 3, 21-27 [in Ukrainian]. 
classification of models, combining them into two large groups: material (physical and analog) and ideal (intuitive and symbolic) ${ }^{35}$ (Levina, 2001).

Sometimes even the formation of readiness for a particular activity is considered by scientists as a conceptual model of this activity (namely, an imaginary picture of the process and conditions of the activity), i.e. a dynamic synthesis of available information and previous experience. The principles of constructing such a model are:

- generalization (display of the most significant constant features of the modeling object);

- schematics (demonstration of the fundamental elements interrelation of a modeling object);

- panoramic feature (display of integrity through structural components) ${ }^{36}$ (Levina, 2001).

According to S. Melnyk, modeling consists of the following stages:

- setting the goal of solving the problem with the help of the model;

- identifying the main components of the system that make up its essence;

- revealing objectively existing interconnections between system components;

- translating the system components into the abstract language (symbolism);

- choosing the ways to depict the model and its construction $^{37}$ (Melnyk, 2006).

${ }^{35}$ Levina, I. A. (2001). Profesiina diialnist uchytelia z formuvannia piznavalnoi samostiinosti pidlitkiv zasobamy modeliuvannia [Teacher's professional activity on forming of teenagers' cognitive independence by means of modeling]. (Dys. kand. ped. nauk). Pivdennoukr. derzh. ped. un-t im. K. D. Ushynskoho, Odesa [in Ukrainian].

${ }^{36}$ Levina, I. A. (2001). Profesiina diialnist uchytelia $z$ formuvannia piznavalnoi samostiinosti pidlitkiv zasobamy modeliuvannia [Teacher's professional activity on forming of teenagers' cognitive independence by means of modeling]. (Dys. kand. ped. nauk.). Pivdennoukr. derzh. ped. un-t im. K. D. Ushynskoho, Odesa [in Ukrainian].

${ }^{37}$ Melnyk, S. V. (2006). Modeliuvannia diialnosti innovatsiinoho navchalnoho zakladu - Shkoly spryiannia zdoroviu [Modeling the activities of an innovative educational institution - Schools for health promotion]. Ridna shkola [Home School], 4, 25-29 [in Ukrainian]. 
Thus, modeling allows you to identify the components that make up a single system clearly, to build relations between them schematically, to highlight the forms, methods, systems of the result evaluation, to set the conditions for the object of the study.

Modeling is one of the main categories of the theory of cognition; any method of scientific research, both theoretical (which uses symbolic, abstract models) and experimental (uses subject models), is based on the idea of modeling ${ }^{38}$ (Prokhorov, 1991).

Modeling considers a real system in a set of elements that are interconnected in a particular way. According to the definition of philosophical dictionaries, a system (from Greek systema - composed of parts, combined) is a set of elements that are interconnected and which create a certain integrity, unity ${ }^{39}$ (Gubskiy, 1997); a system is an ordered set of interrelated elements that have their own structure and organization $^{40}$ (Shynkaruk, 1986). These definitions indicate that the concept of a system implies such notions as an element and a structure. An element is an indivisible system component in the context of a particular system and its specific consideration and analysis ${ }^{41}$ (Shynkaruk, 1986).

In I. Levina's research, modeling is considered as the research of objects of cognition on their models, the construction (analysis and study) of models and objects (systems, structures, processes, etc.). The author has defined the following main stages in modeling:

1) setting the task;

2) creating and selecting a model to study the original;

3) the model studying;

4) transferring the data obtained by analyzing the model to the original $^{42}$ (Levina, 2001).

${ }^{38}$ Prokhorov, A. M. (Red). (1991). Bolshoy entsiklopedicheskiy slovar [Great Encyclopedic Dictionary]. Moskva: Sov. Entsiklopediya [in Russian].

39 Gubskiy, Ye. F. (Red). (1997). Filosofskiy entsiklopedicheskiy slovar [Philosophical Encyclopedic Dictionary]. Moskva: INFRA [in Russian].

40 Shynkaruk, V. I. (Red). (1986). Filosofskyi slovnyk [Philosophical Dictionary] Kyiv: Holovna redaktsiia URE [in Ukrainian].

${ }^{41}$ Shynkaruk, V. I. (Red). (1986). Filosofskyi slovnyk [Philosophical Dictionary] Kyiv: Holovna redaktsiia URE [in Ukrainian].

${ }^{42}$ Levina, I. A. (2001). Profesiina diialnist uchytelia z formuvannia piznavalnoi samostiinosti pidlitkiv zasobamy modeliuvannia [Teacher's professional activity on forming of teenagers' cognitive independence by means of modeling]. (Dys. kand. ped. nauk.). Pivdennoukr. derzh. ped. un-t im. K. D. Ushynskoho, Odesa [in Ukrainian]. 
Developing the prognostic model of the interaction of the subjects of moral-psychological support for maintaining the mental health of the border guards in special and/or extreme conditions of their professional activity (Fig. 1), we have used a systematic approach that “... in psychology ... allows to integrate and systematize the accumulated knowledge, to overcome their extreme redundancy, to find invariants of psychological descriptions, to bypass the local approach disadvantages, to increase the effectiveness of system researches and the learning process, to formulate new scientific hypotheses, to create systematic descriptions of mental phenomena",43 (Ganzen, 1984). According to V. Barabanshchykov, “... a systematic approach allows to define the research problem most precisely and to outline its solution strategy; it focuses the researcher on the study of the psyche as a differentiated unit, revealing the diversity of its connections and plans, levels and dimensions; it provides the creation of an extremely wide multidimensional picture of mental phenomena"44 (Barabanshchikov, 1997).

The main subjects of moral and psychological support in the State Border Guard Service are: the State Border Guard Service administrative staff, border guard divisions, departments of the border guard inspectors, support units, military chaplains, integrity inspectors, military collective groups (officers' meetings), freelance groups of internal communications.

We should analyze the measures taken by the subjects of moral and psychological support for maintaining the mental health of the border guards in special and/or extreme conditions of their professional activity in details.

Diagnostic measures include:

- the use of diagnostic tools, observation methods, surveys, expert assessment, etc.;

- analysis of the received information, interpretation of the diagnosis results;

43 Ganzen, V. A. (1984). Sistemnyye opisaniya v psikhologii [System descriptions in psychology]. Leningrad: LGU [in Russian].

${ }_{44}$ Barabanshchikov, V. A. (1997.). Printsip sistemnosti v psikhologicheskoy kontseptsii B. F. Lomova [The principle of consistency in the psychological concept of B. F. Lomov]. Psikhol. zhurn [Psychological Journal], T. 18, 1. P. 3-9 [in Russian]. 


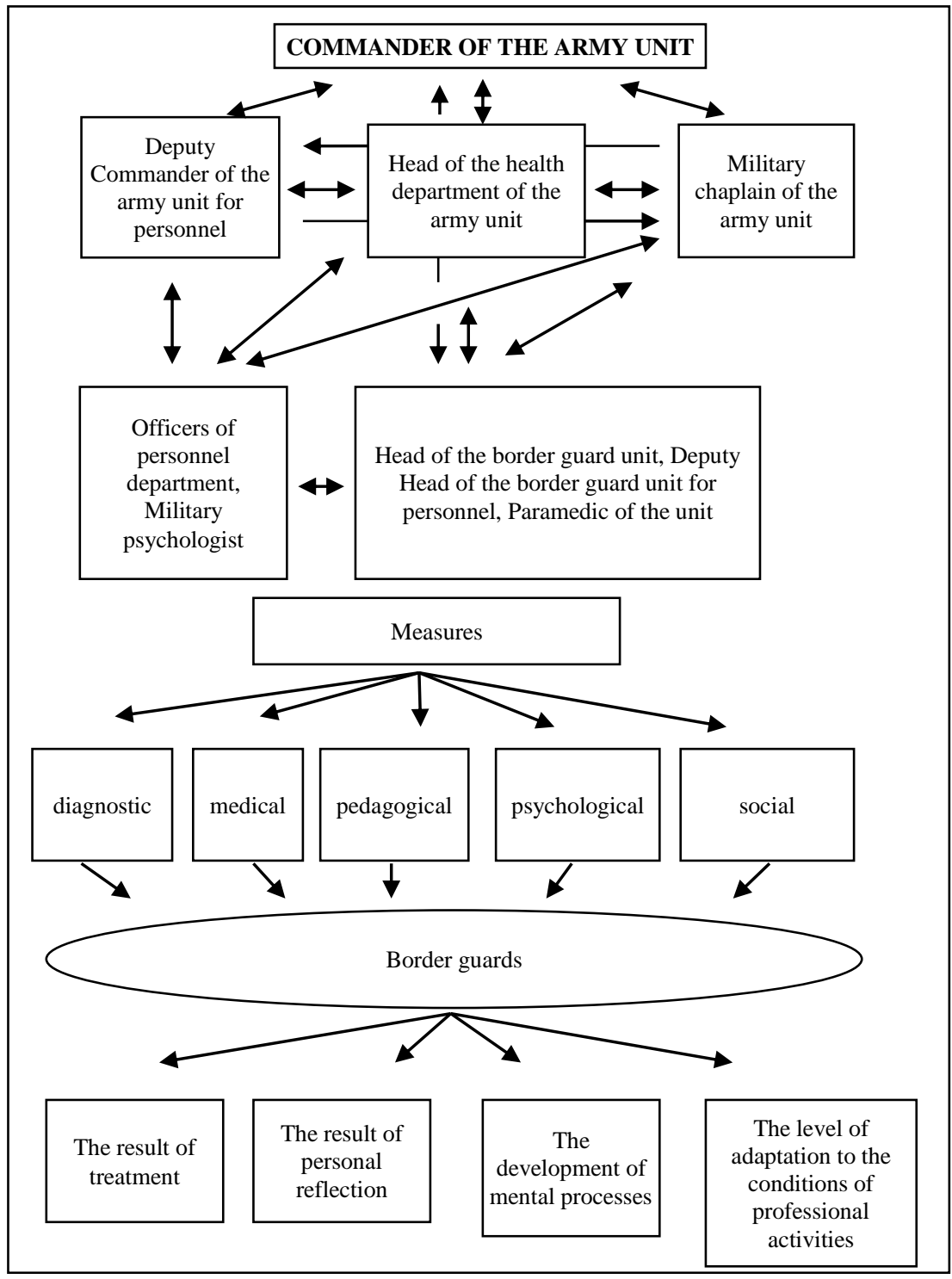

Fig. 1. The prognostic model of the interaction of the subjects of moral and psychological support for maintaining the mental health of the border guards in special and/or extreme conditions of their professional activity 
- determining the nature of the problem concerning the mental state of the military man;

- determining the most effective method of psychological assistance.

Medical measures include:

- medical examination of the border guards with mental health problems;

- carrying out preventive and rehabilitation measures, consultations;

- diagnosis and treatment of mental disorders;

- ensuring all types of compulsory medical measures;

- carrying out medical treatment together with a set of rehabilitation measures to re-socialize the border guards;

- active supervision, control of ambulatory treatment for the prevention of exacerbation of the disease, subject to the principle of voluntariness in the medical care provision;

- conducting preliminary and periodic psychiatric examinations;

- medical examination of recruits.

Pedagogical measures include:

- conducting classes and training with military personnel on improving their professional level;

- conducting talks and briefings on humanitarian themes;

- moral education of military men. In the basis of this process, there is an aspiration for the highest human values: the humanistic ideals of harmony, charity, truth, justice; predominance of altruistic motives, willingness to waive one's own interests for the sake of other people's ones.

Psychological measures are planned on the basis of diagnostic results and involve purposeful interaction with the military man to assist him in solving his psychological problems. The main forms of the work are the use of elements of cognitive-behavioral and physical therapy as well as psychological counseling and psychological support. Psychological support includes:

- regular observation of the behavior and service activities of military personnel by the psychologist, control over the implementation of the psychologist's recommendations;

- briefing, teaching the close social environment of the military man (commanders, comrades, family members) the necessary features 
of behaving with him, the methods and forms of providing psychological support, and monitoring the implementation of these recommendations;

- carrying out additional psychological consultations if it is necessary. When providing psychological help, both individual and group forms of work are provided.

Social measures include:

- development of culture and spirituality of the border guards;

- military and patriotic education of the border guards;

- conducting creative competitions, festivals and other events;

- organization of work on the implementation of social and legal guarantees of social protection of military personnel and their family members.

This list of activities is not complete and will be further elaborated.

Therefore, the introduction of the proposed prognostic model in the State Border Guard Service of Ukraine, in our opinion, will not only provide the maintenance of the mental health of the border guards in special and/or extreme conditions of professional activity, but also promote their professional and psychological development.

\section{CONCLUSION}

We should ascertain that, unlike foreign science (L. Hourani, J. Morgan, S. Tueller, M. Lane and other scientists), the topic of psychological activity of the military chaplains concerning the maintenance of military personnel's mental health is only beginning to be studied in the Ukrainian psychology, although, in the context of the cooperation between the Ukrainian church and military institutions, the problem was analyzed by such scientists as: V. Bondarenko, M. Vasiv, L. Vladychenko, S. Zdioruk, V. Yelenskyi, Y. Kalnysh, S. Lysenko, Y. Reshetnikov, S. Somin, O. Utkin and others. Some issues of pastoral care in the system of maintaining the mental health and upbringing of believing military personnel were studied by: A. Afanasiev, V. Dibrova, P. Kostiuk, R. Kohanchuk, M. Morozov, O. Melnyk. The works, which outline approaches to determining the directions, forms and methods of the clergy activity in the Armed Forces of Ukraine and of other states, are of considerable interest 
(O. Varnashova, L. Vygovskyi, A. Zhalovaha, E. Zabzaliuk, S. Semenov, T. Thorzhevska).

The essence of pastoral activities of military chaplains in the work with border guards can be reflected in:

- education of highly patriotic feelings and fighting spirit on the basis of the moral and spiritual potential of the religious and cultural heritage of the Ukrainian people;

- assistance to the military personnel in the development of their personal and collective moral traits and qualities: brotherhood, courage, bravery, responsibility, moderation, sacrifice, discipline, prudence;

- participation in the rehabilitation of the military personnel which need psychological assistance, since the ordinary military man may not always want to share the problems, which are of great concern for them, with a unit commander or a military psychologist.

The effective problem resolving concerning the active involvement of the military chaplains in maintaining the mental health of the border guards will contribute to the implementation of the Government-approved Program (July 12, 2017 № 475-r) of the State Target Program for physical, medical, and psychological rehabilitation and social and professional re-adaptation of anti-terrorist operation participants who took part in the implementation of measures for national security and defense, repulsion and deterrence of armed aggression of the Russian Federation in Donetsk and Luhansk regions, providing their implementation for the period up to 2022 .

\section{SUMMARY}

The article deals with the problems of maintaining the mental health of the border guards in special and/or extreme conditions of their professional activity with involvement of the military chaplains at the present stage of development of the State Border Guard Service of Ukraine and proposals for its improvement. The deviant behavior of the military personnel in the form of suicidal and addictive behavior has been analyzed. The possibility of preventing the deviant behavior of the border guards in special and/or extreme conditions of their professional activity by means of the pastoral activity of the military chaplains has been considered. The prognostic model of the interaction of the moral and psychological support subjects in maintaining the 
mental health of the border guards in the special and/or extreme conditions of their professional activity is proposed.

\section{REFERENCES}

1. Aleshchenko, V. I., Safin O. D., Potapchuk Ye. M. (2007). Orhanizatsiia zabezpechennia zberezhennia psykhichnoho zdorovia viiskovosluzhbovtsiv [Organization of maintenance of mental health of military personnel]. Kyiv [in Ukrainian].

2. Barabanshchikov, V. A. (1997). Printsip sistemnosti v psikhologicheskoy kontseptsii B. F. Lomova [The principle of consistency in the psychological concept of B. F. Lomov]. Psikhol. zhurn [Psychological Journal], T. 18, 1. P. 3-9 [in Russian].

3. Busel, V. T. (Red). (2005). Velykyi tlumachnyi slovnyk suchasno ukrainskoi movy [A great explanatory dictionary of modern Ukrainian]. Kyiv: Perun [in Ukrainian].

4. Derzhavna sluzhba statystyky Ukraiiny [State Statistics Service of Ukraine]. (2018). Lyst [Letter]. Retrieved from: ps://dostup.pravda.com.ua/request/34337/response/76881/attach/2/15.2 $\% 2020 \% 20770 . p d f$ [in Ukrainian].

5. Durkheim, E. (1994). Samoubiystvo: Sotsiologicheskiy etyud [Suicide: A sociological study]. Moskva: Mysl [in Russian].

6. Filonenko, M. M. (2015). Psykholohiia osobystisnoho stanovlennia maibutnoho likaria [Psychology of personality formation of the future doctor]. Kyiv: Tsentr uchbovoii literatury [in Ukrainian].

7. Ganzen, V. A. (1984). Sistemnyye opisaniya $v$ psikhologii [System descriptions in psychology]. Leningrad: LGU [in Russian].

8. Grishin, Ye. A. (Red). (1994). Sovremennyy slovar inostrannykh slov [Modern dictionary of foreign words]. Sankt Peterburg: Duyet [in Russian].

9. Gubskiy, Ye. F. (Red). (1997). Filosofskiy entsiklopedicheskiy slovar [Philosophical Encyclopedic Dictionary]. Moskva: INFRA [in Russian].

10. Kalenychenko, T., Kokhanchuk, R. (2017). Buty poruch. Osnovy viiskovoho kapelanstva dlia viiskovykh $i$ volonteriv [To be near. Basics of military chaplaincy for military personnel and volunteers]. (2-e vydannia). Kyiv: Makhanaym Prynt [in Ukrainian] [in Ukrainian]. 
11. Kalenychenko, T. A. (2018). Relihiina skladova suspilnopolitychnoho konfliktu kintsia 2013-2017 rr. v Ukraiini [The religious component of the socio-political conflict of the end of 2013-2017 in Ukraine]. (Dys. kand. filosof. nauk). Nats. ped. un-t. im. M. P. Drahomanova, Kyiv [in Ukrainian].

12. Karayani, A. G. (2006). Prikladnaya voyennaya psikhologiya [Applied Military Psychology]. Sankt-Peterburg: Piter [in Russian].

13. Kikalishvili, M. (2001). Deviantna povedinka: poniattia ta oznaky [Deviant behavior: concepts and features]. Visnyk Akademiii advokatury Ukraiiny [Bulletin of the Academy of Advocacy of Ukraine], 3(22), 109-122. Retrieved from: irbis-nbuv.gov.ua/cgibin/irbis_nbuv > cgiirbis_64 > vaau_2011_3_17 [in Ukrainian].

14. Kon, I. S. (1967). Sotsiologiya lichnosti [Sociology of personality]. Moskva: Politizdat [in Russian].

15. Kon, I. S. (1997). Vkus zapretnogo ploda [The taste of the forbidden fruit]. Moskva: Semya i shkola [in Russian].

16. Levina, I. A. (2001). Profesiina diialnist uchytelia z formuvannia piznavalnoi samostiinosti pidlitkiv zasobamy modeliuvannia [Teacher's professional activity on forming of teenagers' cognitive independence by means of modeling]. (Dys. kand. ped. nauk). Pivdennoukr. derzh. ped. un-t im. K. D. Ushynskoho, Odesa [in Ukrainian].

17. Lichko, A. Ye. (1983). Eti trudnyye podrostki [These difficult teens]. Moskva: Meditsina [in Russian].

18. Melnyk, S. V. (2006). Modeliuvannia diialnosti innovatsiinoho navchalnoho zakladu - Shkoly spryiannia zdoroviu [Modeling the activities of an innovative educational institution - Schools for health promotion]. Ridna shkola [Home School], 4, 25-29 [in Ukrainian].

19. Melnyk, Ya. I. (2016). Psykhoprofilaktyka deviantnoi povedinky viiskovosluzhbovtsiv $v$ osoblyvykh umovakh diialnosti [Psychoprophylaxis of deviant behavior of military personnel in special conditions of activity]. (Dys. kand. psykhol. nauk). Natsionalna akademiia Derzhavnoii prykordonnoii sluzhby im. B. Khmelnytskoho [in Ukrainian].

20. Meshcheryakova, B. G., Zinchenko, V. P. (Red). (1983) Psikhologicheskiy slovar [Psychological Dictionary]. Moskva: AST [in Russian]. 
21. Mykhailiuk, I. R. (2001). Pedahohichni umovy ta model formuvannia hotovnosti do pedahohichnoi diialnosti mahistriv tekhnichnoho spriamuvannia [Pedagogical conditions and model of forming the readiness for pedagogical activity of masters of technical direction]. Visnyk Natsionalnoi akademii Derzhavnoi prykordonnoi sluzhby Ukrainy [Bulletin of the National Academy of the State Border Guard Service of Ukraine], 3, 21-27 [in Ukrainian].

22. Moskalets, V. P. (2004). Psykholohiia relihii [Psychology of religion] : posibnyk. Kyiv: Akademvydav [in Ukrainian].

23. Nepipenko, L. P. (2017). Problemy ta perspektyvy instytualizatsii viiskovoho dukhovenstva (kapelanskoi sluzhby) $v$ Ukraini [Problems and Prospects of Institutionalization of the Military Clergy (Chaplaincy Service) in Ukraine], Naukove zabezpechennia sluzhbovo-boiovoi diialnosti Natsionalnoi hvardii Ukrainy [Scientific Support for Service and Combat Activity of the National Guard of Ukraine], zb. materialiv dop. uchasn. VIII nauk.-prakt. konf. Kharkiv: NANHU. Retrieved from: http://nangu.edu.ua/wp-content/ uploads/2017/04/3бірник-тез-2017_секція-4.pdf [in Ukrainian].

24. Ovcharova, L., Movchan, A. (2018). Technologies of social work with persons easy to suicide Reporter of the priazovskyi State technical University Section: Socially-humanitarian sciences and public administration, 1, 119-122 [in English]

25. Pobirchenko, N. A. (Red). (2007). Psykholohichnyi slovnyk [Psychological Dictionary]. Kyiv: Naukovyi svit [in Ukrainian].

26. Poplavska, S. D. (2009). Model formuvannia hotovnosti studentiv medychnykh koledzhiv do komunikatyvnoi vzaiemodii $u$ profesiini diialnosti [Model of forming the readiness of students of medical colleges for communicative interaction in the professional activity]. Visnyk Zhytomyrskoho DU im. I. Franka [Bulletin of I. Franko Zhytomyr State University], 46, 92-96 [in Ukrainian].

27. Potapchuk, Ye. M. (2004) Sotsialno-psykholohichni osnovy zberezhennia psykhichnoho zdorovia viiskovosluzhbovtsiv [Sociopsychological bases of maintaining mental health of military personnel]. (Dys. d-ra psykhol. nauk) Natsionalna akademiia Derzhavnoi prykordonnoi sluzhby im. B. Khmelnytskoho, Khmelnytskyi [in Ukrainian].

28. Predko, O. I. (2005). Psykholohiia relihii: istoriia, teoriia, relihiieznavchi vymiry [Psychology of Religion: History, Theory, 
Religious Dimensions]. Kyiv: Tsentr navchalnoi literatury [in Ukrainian].

29. Prokhorov, A. M. (Red). (1991). Bolshoy entsiklopedicheskiy slovar [Great Encyclopedic Dictionary]. Moskva: Sov. Entsiklopediya [in Russian].

30. Reber, A. (Red). (2003). Bolshoy tolkovyy psikhologicheskiy slovar [Great explanatory psychological dictionary]. (T. 1 (A-O)). Moskva: AST [in Russian].

31. Romanyshyn, A. M. (Red). (2017). Profilaktyka vidkhylnoi povedinky $u$ viiskovosluzhbovtsiv [Prevention of deviant behavior of military personnel]. Lviv: NASV [in Ukrainian].

32. Samohubstva v armii [Suicide in the Army]. (2018, liutyi 26). Ukrainska Pravda [The Ukrainian Truth]. Retrieved from: https://www.pravda.com.ua/news/2018/02/26/7172855 [in Ukrainian].

33. Shynkaruk, V. I. (Red). (1986). Filosofskyi slovnyk [Philosophical Dictionary] Kyiv: Holovna redaktsiia URE [in Ukrainian].

34. Spirina, T. P. (2008). Model formuvannia profesiinoi kultury maibutnikh sotsialnykh pedahohiv [Model of professional culture formation of future social educators]. Visnyk Prykarpatskoho universytetu : pedahohika [Bulletin of the Carpathian University : Pedagogy], 21, 278-291 [in Ukrainian].

35. Vlada znaie ne vse... [The authorities do not know everything...] OBOZREVATEL.ua. [OBSERVER.ua] Retrieved from: https://www.obozrevatel.com/ukr/crime/statistika-zanizhena-veteranato-rozpoviv-pro-vbivstva-i-suitsidi-v-armii.htm [in Ukrainian].

36. Vsesvitnia orhanizatsiia okhorony zdorovia [World Health Organization]. Retrieved from: https://www.who.int/ru/news-room/factsheets/detail/mental-health-strengthening-our-response [in Ukrainian].

\section{Information about the author: Artem Makovskyi,}

Postgraduate student of the Military Postgraduate School National Academy of the State Border Guard Service of Ukraine named after Bohdan Khmelnytskyi 46, Shevchenko str., Khmelnytskyi, 29003, Ukraine ORCID ID: orcid.org/0000-0003-2903-3351 E-mail: makovski200844@gmail.com 